\title{
DIVERSIFICATION OF BEVERAGE PRODUCT BASED ON VEGETABLES AND FRUITS IN KRAMAT JATI
}

\author{
Shanti Pujilestari, Julfi Restu Amelia, Siti Chairiyah Batubara \\ Universitas Sahid, Indonesia. \\ shanti_pujilestari@usahid.ac.id
}

\begin{abstract}
Mother's knowledge in processing vegetable and fruit-based beverage products that have the potential to add value is still lacking. The community does not see any business opportunities from raw materials for vegetables and fruits. Besides these two things, the vegetable and fruit planting program for urban homes with narrow yard has been carried out in the previous service program. This activity can result in an excess harvest. The proposed solutions are: (1) Holding active participation activities in PKK group; (2) Motivation for increasing processed vegetables and fruit based drinks is hed; (3) training for processing vegetable and fruit-based beverage products. The methods in this program are: (1) Participatory approach of PKK group; (2) Providing motivation for participants to increase the value of vegetables and fruit; and (3) training on processing vegetables and fruit based beverage products. The results of the activities are: (1) Active participation in PKK has been carried out; (2) Motivation has been done for participants to increase the value of vegetables and fruit; and (3) training for processing vegetable and fruit-based beverage products has been conducted.
\end{abstract}

Keywords: Diversification, Fruit, Vegetable, Beverage, Greening, PKK Group

\section{INTRODUCTION}

Kampung Tengah Village has an area of $1.98 \mathrm{~km} 2$ or occupies $15.23 \%$ of the Kramat Jati area. The population of Kramat Jati Central Village in 215 was 49,917 people. The number of men is 25,429 and the number of women is 24,488 (BPS, 2016). RW 10 Kampung Tengah Kramat Jati people are mostly people who live in houses that are coinciding. Mother is a food manager in the household, however, she has a greater opportunity to produce vegetable and fruit based beverage products from other family members. Therefore the activity partners are the PKK. Opportunities for the community are processing food products from upstream to downstream. Starting from raw plants, namely vegetables such as spinach, carrots, cucumber, pineapple, lime and squeezed oranges to processed drinks that can be made for example mixed drink squeezed cucumber squeezed as a powder so that it can be stored in a long time and can be directly brewed for consumption. The form of processed is intended to add value to a product so that after harvesting it can be stored for a long time and can be an income enhancer or open business opportunities. If this opportunity can be utilized well by the community, it is not impossible that the community will prosper. This means that the household food independence program that was launched by the DKI Jakarta government several years ago can be achieved.

Before 2003 there was an extraordinary reforestation in Kramat Jati, even in RW 10 Kampung Tengah Village there were community leaders who had received government awards for having large tracts of land that were only intended for vegetable and fruit crops in the middle of the city. After 2003 community involvement in a green environment has declined, even in 2010 the community's desire to start reforesting has increasingly disappeared. This is due to the lack of support for the farming program, especially support from the top down, that the focus of the Rukun Warga (RW) level is no longer on the greening problem. The issue of greening was overcome by implementing a vegetable and fruit planting program for homes in urban areas with narrow yards. The technology used is the planting of vegetables and fruit in vertical gutters. This technology has been modified so that water usage efficiency occurs. This activity has been carried out in a previous service program (Amelia et al., 2018). Planting vegetables and fruit can lead to excess harvest. Another problem is the boredom of family members to raw vegetables and fruit. From the problems that have been presented, the proposed solutions are: (1) The holding of active participation in PKK group; (2) Motivation for increasing processed vegetables and fruit based drinks is held; and (3) training for processing vegetable and fruit-based beverage products.

\section{METHODS}

The method used is:

1. Approach to active participation by contacting family members who are active in PKK using the PRA method (Chamber, 1992).

2. Providing training to motivate participants to increase the value of vegetable and fruit based products through processing vegetables and fruit based drinks

3. Training on processing of vegetable and fruit based beverage products. 
To implement the empowerment method, the following stages of activity are carried out:

1. The first step is to look for and gather facts and information related to data on problems of PKK group

2. The second phase, focused discussions with all stakeholders to get support and participation from mothers who are classified as active from PKK

3. The third step is to make an activity plan table that contains activities, time, location, costs, tools, materials, modules and indicators of achievement.

4. The fourth stage, making invitations and coordinating with one of the PKK group who can help coordinate the activities of the week before the activity takes place

5. The fifth stage, make an activity report and distribute it to those who need it

6 . The sixth stage, disseminating the results of activities in the seminar

\section{RESULTS AND DISCUSSION}

\section{Active community participation}

The first activity is to build active participation from the community, starting from exploring problems, finding solutions, methods, planning, implementing, monitoring and evaluating. Active participation through focused discussion at a meeting with all stakeholders. This meeting was held on Monday, 20 August 2018. An active participatory approach with PKK women can be seen in Picture 1.

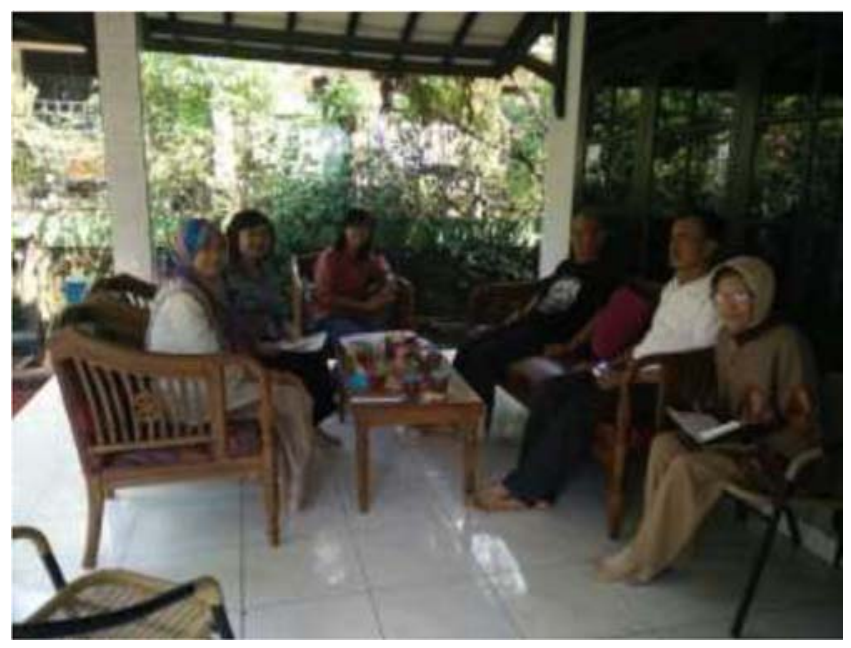

Picture 1. Approach to active participation with PKK women

The PKK women were facilitated to discuss the problem of the possibility of over-harvesting or boredom in fresh vegetables and fruit plants to the utilization of vegetable and fruit plants as raw materials for beverage products that have business potential. In every activity PKK women are expected to have full involvement and can influence other members to actively participate in this activity. At this stage, the women who were invited to discuss in depth about the problem of using vegetables and fruit that had been planted began to be active in finding problems and finding solutions. The women began to comment on the proposed schedule and activities to be carried out. The final result of this meeting is the Chairperson of PKK RW 10 and RW 10 will support and play an active role in the processing of vegetables and fruit-based beverage products. This is in accordance with the theory of Chamber (1992) which states that people can understand the problem and can solve the problem independently. In addition to the PKK women as training participants, a meeting with the Lurah was also held. Karang Tengah Village Chief Kramat Jati also supports training in processing vegetables and fruit-based beverage products. Support for activities by the Karang Tengah Urban Village can be seen in Picture 2. 


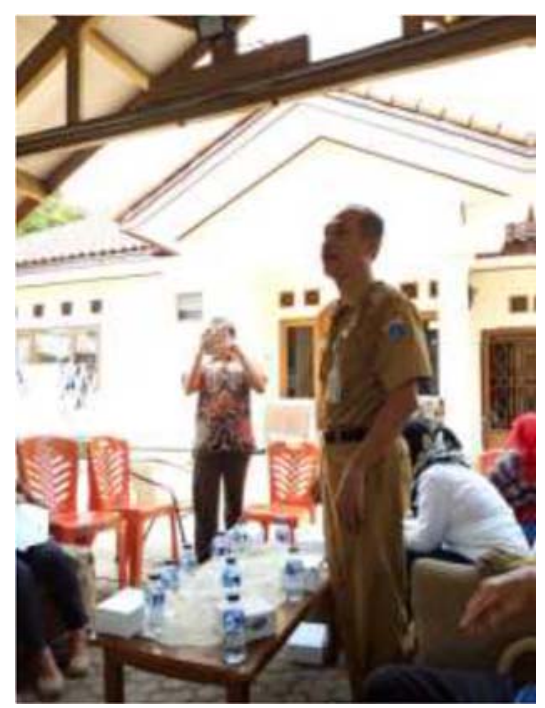

Picture 2. Support for activities by the Karang Tengah Village chief

The support of the Karang Tengah Urban Village is very important. The headman can urge PKK women to play an active and total role in participating in the activities carried out by the community service team.

\section{Motivation for Beverage Products}

The second activity is to provide motivation for participants to increase the value of beverage products through processing vegetable and fruit-based beverage products. This activity was held on Tuesday, October 9, 2018. On this occasion, the beverage product processing program was also socialized. Motivation in processing vegetables and fruit based drinks can be seen in Picture 3.

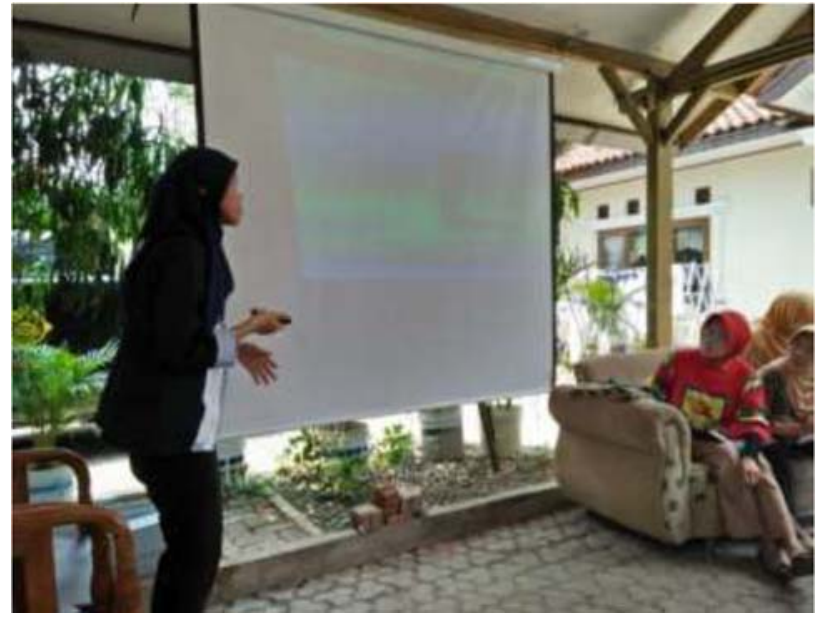

Picture 4. Motivation in processing vegetables and fruit products

Picture 4 shows that motivational activities on processing vegetable and fruit products have taken place. All enthusiastic women want to know immediately how to process various vegetable and fruit based beverage products.

\section{Diversification training on vegetable and fruit based beverage products}

The third activity was the implementation of diversification of vegetable and fruit-based beverage products carried out on Monday, October 15, 2018. Participants were divided into 5 groups each consisting of 5-6 members. The training activities began with the introduction, distribution of modules, and the delivery of material about the nutritional content of vegetables and fruits which generally consisted of vitamins, minerals and fiber which were important for health. After that, the procedure for processing each product was delivered, namely BATELNAS (a beverage made from spinach, carrots, pineapple). Cucumber lime powder (in the form of powder with raw materials of cucumber and lime), TUREKES (a form of powder made from carrots and peres that can be diluted into drinks), and corn drinks. The practice of making 4 types of drinks is carried out by all groups so they try all products. All 
participants seemed enthusiastic about trying all the products practiced even though they looked tired. The training activities take place well, enthusiastic and fun. Training on processing vegetables and fruit based drinks can be seen in Picture 4.
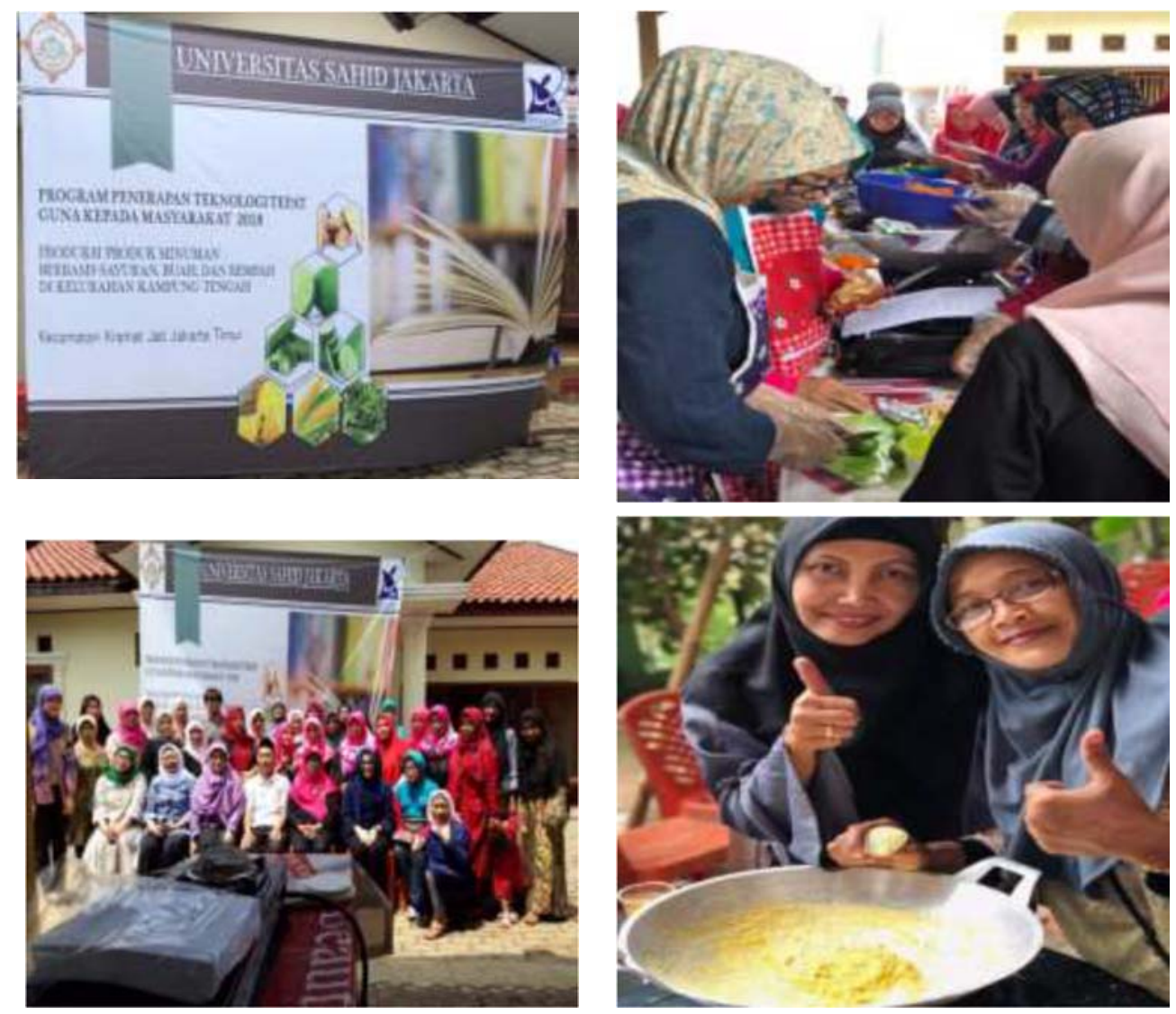

Picture 4. Training on processing of vegetable and fruit based beverage products

Picture 4 shows training in processing vegetable and fruit based beverage products. Picture 4 shows how to make powder with a simple tool, which is a frying pan. This shows that the processed beverage products that are studied use simple tools, making it easier for people to produce them. If the greening program through the planting of vegetables and fruit is successfully accompanied by the processing of various beverage products, the processing of products from upstream to downstream in RW 10 Kampung Kramat Jati is successfully carried out so that the independence of household food that was launched by the DKI Jakarta government a few years ago. Powder drinks are more durable than liquid drinks. In this beverage processing training the powder form are Cucumber Lime Powder and TUREKES while the drinks (liquid) form is BATELNAS and corn drinks. Results of processed vegetables and fruit based drinks can be seen in Picture 5.

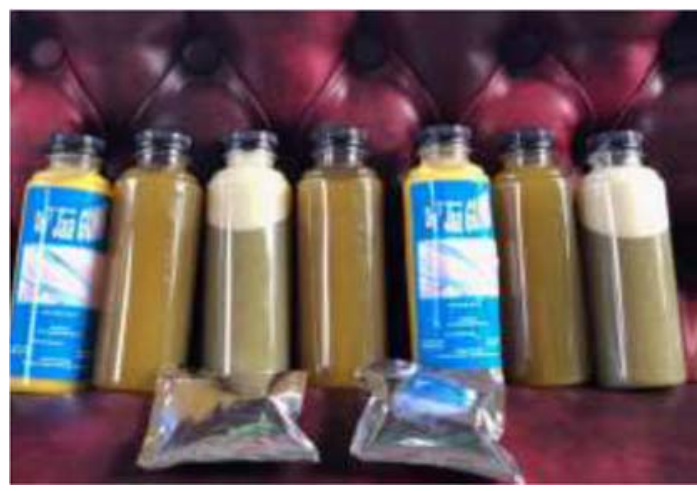

Picture 5. Vegetable and fruit based beverage products 
Picture 5 shows a Vegetable and Fruit based beverage product that is the result of the trainee's direct practice. In Picture 4 you can see that the beverage product is already packaged. Packaging in bottle-covered products in the form of drinks (liquid) and packaging such as sachset packaging for products in the form of powder. The packaging process is still limited to practicing filling drinks into bottles or sachet packaging. The label used is also not perfect. Evaluations of activities include the presence of positive responses from training participants. They find this training very interesting. They will also try to make it at home, even participants will ask for training with other products added.

\section{CONCLUSION}

1. The achievement of active community participation by understanding the problem of finding a solution

2. The implementation of training to motivate participants to increase the value of vegetable and fruit based products through processing vegetables and fruit based drinks

3. Implementation of training on processing vegetables and fruit based beverage products.

\section{ACKNOWLEDGMENT}

Acknowledgments were conveyed to the Directorate of Research and Community Development-Directorate General of Higher Education (DRPM-DIKTI) Ministry of Research and Higher Education which has financed this activity.

\section{REFERENCES}

Badan Pusat Statistik (BPS). (2016). Statistik Daerah Kramat Jati 2016. Tersedia pada : http://www.jaktimkota.bps.go.id

Chambers, R. (1992). Participatory Rural Apprisal (PRA). Memahami Desa Secara Partisipatif. Yogyakarta : Kanisius dan Oxfam.

Amelia J.R., Mulyawati, I., dan Ratnasari L. (2018). Pemanfaatan Tanaman Pangan Pekarangan sebagai Media Penghijauan Produk Olahan Pangan Bernilai Ekonomis di Kelurahan Kampung Tengah Kramat Jati. Laporan Program Penerapan Teknologi Tepat Guna kepada Masyarakat Kementrian Riset, Teknologi dan Pendidikan Tinggi.

Indriyati F. dan Assah YF. (2015). Pengaruh Penambahan Gula dan Sari Buah terhadap Kualitas Minuman Serbuk Daging Buah Pala. Jurnal Penelitian Teknologi Industri. 7(1): 49-60. 